define.php?term $=$ Deus +

Ex+Machina, 14.13, 19 maret

2016

Mahayana. Maman.S, 2009, Sastra

Bandingan: Pintu Masuk

Kajian Budaya. Jakarta.

Newton.P, Ed, dkk, 1990, Sastra

Perbandingan: Kaedah dan

Perspektif, terj. Sahlan,

Mohd Saman. Kuala Lumpur:

Dewan Bahasa dan Pustaka,

Kementrian pendidikan

Malaysia.

Pak Belalang diunduh dari http:// cintailahceritarakyat.blogspot. co.id/2011/03/nujum-pakbelalang.html 14.20. 10 maret 2016

Saman, Mohd Sahlan, 1983, Sastra Bandingan: Konsep. Teori dan Amalan. Kuala Lumpur.

Suwardi Endaswara, 2002, Metodologi Penelitian Folklor; konsep, Teori dan Aplikasi. Yogyakarya: Med Press.

Weisstein, Ulrich, 1973, Comparative Literature and Literary Theory, Indiana Univ Press. 


\title{
RELEVANSI KEHIDUPAN SEHARI-HARI DENGAN SENI PERTUNJUKAN TRADISIONAL
}

\author{
Jefrizal \\ Staf pengajar Fakultas Ilmu Budaya, Unilak
}

\begin{abstract}
This writing deals with the relevance of daily life and traditional theatre performance, tonil. In this case, the traditional theatre performance focuses only on the existence and phenomena of Ogam in the life of Bengkalis' people in which it is related to the people'a theatre performance. Ogam is a simple chat people utter in some conditions. The better the people chat, the more successful those people attract other attention. In certain situation, it is also found that someone doesn't chat properly and it may cause uncomfortable chat and it may also stop the interesting chat. This ogam is signed by many coffee shops found in Bengkalis in which people usually spend their time practising ogam in those coffee shops. In traditional theatre performance, the actor or actress do not use script, so the skill in Ogam is very useful to improvise.
\end{abstract}

Keywrods: Ogam, Bengkalis, traditional theatre performance.

\section{A. Pendahuluan}

Membicarakan keberadaan seni pertunjukan tradisional tentu saja tidak bisa lepas dari membincangkan kehidupan masyarakat pendukungnya. Tak heran, dalam setiap unsur seni pertunjukan tradisonal yang ada, terdapat hubungan dan kait kelindan dengan kehidupan sehari-hari masyarakat pendukungnya, baik berupa nilai, fenomena, simbol dan lain sebagainya.

Namun dengan derasnya berbagai sarana komunikasi maupun informasi ternyata cukup besar berpengaruh terhadap keberadaan seni pertunjukan tradisional. Kelompok-kelompok kesenian tradisional mulai menghilang, karena tiadanya faktor penyangga baik dalam bentuk dana, kamampuan ataupun regenerasinya. Oleh karena itu, mereka tidak dapat bersaing dengan munculnya bentuk-bentuk kesenian modern yang lebih diminati oleh masyarakat sekarang.

Sehingga dengan demikian bila seni pertunjukan tradisional itu dirasa sudah "tidak berfungsi", dengan sendirinya keberadaannya akan menghilang dari masyarakat pendukungnya. Padahal pada dasarnya seni pertunjukan tradisional 
secara umum mempunyai empat fungsi utama yaitu fungsi ritual, fungsi pendidikan, sebagai media penuntun, sebagai media penerangan atau kritik sosial dan sebagai fungsi hiburan atau tontonan.

\section{B. Yang Tradisional dan Yang Tidak}

Secara sederhana, predikat tradisional bisa diartikan sebagai segala sesuatu yang sesuai dengan tradisi, sesuai dengan kerangka dan pola-pola bentuk maupun penerapan yang selalu berulang-ulang, sedang yang tidak tradisional adalah yang tidak terikat pada kerangka apapun.

Tetapi apabila kita menghadapi karya-karya seni pertunjukan yang nyata, tidak selalu mudah untuk menentukan karya tersebut tradisonal atau tidak. Kita harus bisa pula mengidentifikasi bentuk dan konsep antara tradisonal dan yang tidak tradisional atau sudah adanya inovasiinovasi baru di dalamnya.

Namun demikian, yang menjadi kata kunci dari tradisonal itu sendiri adalah adanya pengulanganpengulangan bentuk, tanpa dijamahi pembaharuan. Karena bagaimanapun, yang namanya tradisional itu terikat dengan nilai-nilai dan keyakinan dari tetua sebelumnya.

\section{Mengembangkan yang Tradisional}

Bagian dari tulisan ini, saya mulai dengan sebuah pertanyaan yaitu, benarkah kesenian tradisonal perlu untuk dikembangkan?

Istilah mengembangkan lebih mempunyai konotasi kuantitatif daripada kualitatif. Artinya membesarkan, meluaskan. Dalam pengertiannya yang kuantitatif itu, mengembangkan seni perrtunjukan tradisional Indonesia berarti membesarkan volume penyajiannya, meluaskan wilayah pengenalannya.

Tetapi menurut penulis, ia juga harus berarti memperbanyak tersedianya kemungkinankemungkinan untuk mengolah dan memperbarui wajah, suatu usaha yang mempunyai arti sebagai sarana untuk timbulnya pencapaian kualitatif. Sebab kualitas sebuah karya seni pertamatama ditentukan oleh lahir atau tidaknya seniman yang mengerjakannya. Dan hal itu tergantung pada perkenan alam untuk memunculkan mutiara-mutiarnya.

Namun kemudian, hal yang tidak kalah pentingnya adalah usaha-usaha untuk menciptakan kondisi sehingga mutiara-mutiara itu bisa muncul dan bisa dilihat. Dalam artinya, yang terakhir inilah maka mengembangkan seni pertunjukan tradisonal sebagai usaha penyiapan prasarana, sedang tujuan terakhir adalah memperbesar kemungkinan berkarya dan membuat 
karya-karya itu berarti bagi sebanyakbanyaknya anggota masyarakat.

Untuk mengatakan "mengembangkan kesenian tradisonal" dan bukan "memupuk pertumbuhan kesenian" mengandung pengertian bahwa yang tradisional harus dipertahankan. Secara singkat dapat dipaparkan alasan-alasan untuk mempertahankan kesenian tradisional, tetapi jelas tidak semata-mata dengan menjadikannya barang mati.

Alasan pertama, sebagaimana yang pernah dijelaskan oleh Edi Setiawati dalam bukunya Pertumbuhan Seni Pertunjukan, adalah bahwa pengenalan secara luas dan sering, keakraban dengan sesuatu yang dikenal mempunyai arti sebagai pembentuk ketentraman awal, semacam bekal minuman, sebagai suatu landasan untuk menggerakkan karya bagi seniman untuk terwujudnya apresiasi bagi si penikmat. Ini semacam kebutuhan pokok untuk menghasilkan tenaga, sedang tenaga ini pada gilirannya bisa menghasilkan perbaikan mutu kebutuhan pokok tersebut.

Artinya, di sini suatu hal yang membuat usaha menghidupkan seni pertunjukan tradisional patut diupayakan, adalah dengan adanya kenyataan arus deras pengaruh dari luar tradisi yang memungkinkan timpangnya keseimbangan. Pandangan yang menganggap sesuatu yang baru sebagai tanda kemajuan, tanda kehormatan, sedang segala sesuatu yang keluar dari rumah sendiri sebagai kampungan, ketinggalan zaman, pada dasarnya disebabkan oleh kekurang kenalan akan perbendaharaan kesenian sendiri, di samping kesenian itu sudah menjadi barang jiplakan yang membosankan. Maka menurut penulis, yang patut diupayakan adalah bagaimana kesenian tradisi itu tidak kehilangan hidupnya, untuk membuatnya senantiasa mampu menyediakan iklim merdeka dalam mewujudkan aspirasi manusia seniman, aspirasi masyarakat.

Berbagai corak masyarakat pendukung tradisi-tradisi kesenian terdapat di Indonesia. Maka mempertahankan seni pertunjukan tradisonal berarti mempertahankan konteksnya yang berbagai ragam itu dan memperkembangkan berbagai konteks tersebut. Di sini tentulah ada berbagai kemungkinan diantaranya, mengembangkan dalam artian menuju kesatuan dan keseragaman atau mempertahankan keserbanekaan.

Jadi, membicarakan 'memperkembangkan' berarti memikirkan adanya pelaku yang menjalankan pimpinan dalam pekerjaan memperkembangkan tersebut. Dengan demikian, yang menjadi persoalan apakah pimpinan itu 
seseorang atau sebuah lembaga, apakah pimpinan itu menjalankan peranannya sebagai penyuruh, pengusaha ataukah pelindung atau penganjur?

Sudah tentu ini tergantung pada berbagai kebutuhan, entah itu kebutuhan konservasi, ataukah penciptaan, kebutuhan keagamaan ataukah hiburan, atau juga kebutuhan di kota atau di desa.

\section{Konteks Seni Pertunjukan Indonesia}

Suatu hal yang diketahui bersama, seni pertunjukan di Indonesia berangkat dari suatu kadaan di mana ia tumbuh dalam lingkunganlingkungan etnik yang berbeda satu sama lain. Dalam lingkungan itulah adat, atau kesepakatan bersama yang turun temurun mengenai prilaku, mempunyai wewenang yang amat besar untuk menentukan rebah atau bangkitnya sebuah kesenian tradisional.

Berikut akan penulis kutip beberapa fungsi seni pertunjukan Indonesia menurut Edi Setiawati. Seni pertunjukan dalam lingkunganlingkungan etnik di Indonesia, sebagai berikut:

- Pemanggil kekuatan gaib

- Menjemput roh-roh pelindung untuk hadir di tempat pemujaan
- Memanggil roh-roh baik untuk mengusir roh jahat

- Peringatan pada nenek moyang dengan menirukan kegagahan maupun kesigapannya.

- Pelengkap upacara sehubungan dengan peringatan tingkat-tingkat hidup seseorang

- Pelengkap upacara sehubungan saat-saat tertentu dalam perputaran waktu

- Perwujudan daripada dorongan untuk mengungkapkan keindahan semata.

Dari fungsi yang ada, tentulah dapat kita dapat merasakan perbedaan dengan selapis pengaruh yang sama berupa suatu sikap berseni yang berasal dari dunia Barat, yaitu suatu sikap untuk menganggap bahwa kesenian adalah kegiatan duniawi semata, dengan masalah keindahan sebagai titik pangkal yang tunggal.

Tetapi kemudian, satu hal yang kemudian dapat disaksikan hari ini, justru adanya kenyataan bahwa seni pertunjukan yang berasal dari lingkungan-lingkungan etnik itu kebanyakan mendapatkan pengembangannya di kota-kota, suatu tempat kedudukan yang mempunyai kelompok umum yang selalu terdapat di mana-mana yaitu untuk menyebut hal-hal yang berhubungan dengan kesenian saja. 


\section{E. Seni Pertunjukan dalam Masyarakat dan Kehidupan}

Melihat bahwa bermacam peranan bisa dipunyai kesenian dalam kehidupan dan peranan itu ditentukan oleh keadaan masyarakat, maka besarlah arti kondisi masyarakat ini bagi pengembangan kesenian. Apalagi kalau kita membicarakan seni pertujukan karena ianya menyangkut hadirnya dua pihak, yaitu penyaji dan penerima.

Kita ketahui, adanya kondisi kemasyarakatan Indonesia yang mengenal perbedaan-perbedaan wilayah keadaan dan di lain pihak pembangunan masyarakat dijalankan untuk menyamaratakan kemakmuran dengan teknik-teknik membangun yang dilandasi oleh norma efisiensi yang seragam.

Suasana kehidupan yang serba bergegas yang didasari oleh kepercayaan akan kekuatan-kekuatan magis berangsur-angsur diubah menuju suatu tata hidup yang dilandaskan pada perhitunganperhitungan rasional. Konsep keluarga besar berubah menuju ke konsep keluarga kecil. Sikap gotong royong bisa bergeser menuju sikap penuh perhitungan. Sedang suatu falsafah efisiensi yang berlebihan bisa membawa anggapan bahwa berolah seni adalah suatu pemborosan. Didorong pula dengan kebutuhan yang nyata akan kesejahteraan material yang lebih baik. Maka pembinaan saranasarana kesenian sering menjadi tersisih. Arah perkembangan dipertegas oleh tidak berfungsinya lagi dalam banyak hal wewenang dalam masyarakat yang semula menjadi pelindung serta pendorong kehidupan kesenian.

Diketahui bahwa seni pertunjukan pada pokoknya adalah suatu yang membutuhkan kelompok dan memberikan suatu pengalaman langsung. Namun seiring dengan kemajuan teknologi, dengan dipakainya alat-alat baru seperti handphone, televisi, internet dan juga film maka apabila suatu pergelaran direkam dan kemudian diputar kembali, sifatnya sebagai suatu pengalaman langsung berubah menjadi berperantara dan sifatnya sebagai suatu peristiwa kelompok mengalami individualisasi penikmatan.

Oleh karenanya, penulis kira jika titik tujuannya adalah mengembangkan seni tradisional, sedang kita melihat bahwa yang disebut seni pertunjukan tradisonal itu memiliki demikian banyak segi masalahnya. Tetapi kemudian, perlu adanya rumusan yang jelas seperti misalnya langkah pertama merumuskan garis besar tujuan yaitu menciptakan Indonesia dalam seni, dengan mempertahankan kebhinnekaan serta membuka seluasluasnya kemungkinan hidupnya daya cipta. 
Kebhinnekaan mempunyai arti yang positif karena ia menimbulkan dinamika. Ragam corak yang berbeda, sikap-sikap yang berbeda serta fungsi yang juga berbeda dalam olah seni dapat saling memperluas pandang antar wilayah budaya etnik yang ada. Kesempatan mengenal secara mendalam suatu olah seni juga dapat merupakan suatu pengalaman yang penuh gairah.

Maka menurut penulis, adalah suatu hal yang penting dalam usaha pengembangan seni pertunjukan tradisonal untuk menghidupkan kesenian itu di lingkungan-lingkungan etniknya sendiri. Membuat ia tetap merupakan kebutuhan masyarakat.

\section{F. Relevansi Seni Pertunjukan Tradisonal Daerah Riau Dalam Kehidupan Berkesenian Masa Kini.}

Seni pertunjukan tradisonal di daerah Riau, sama seperti seni pertunjukan tradisonal di manapun yang ada di Indonesia ini. Semuanya merujuk pada seni pertunjukan yang diciptakan dan dihayati oleh seniman dan masyarakat tradisonal pada masa dahulu. Sebagian dari hasil kesenian itu masih dihayati secara baik oleh masyarakat pendukungnya. Sebagian telah luntur dan lusuh. Ada pula yang merana terbiar begitu saja dan tak heran pula jika ada yang lesap ditelan masa sehingga tidak meninggalkan bekas kepada generasi hari ini.

Yang terpikirkan kemudian, adalah bagaimana hari ini misalnya kita berusaha untuk menghidupkan kembali berbagai macam jenis seni pertunjukan tradisional seperti yang dipergelarkan pada masa lampau. Penulis kira, hendaklah terlebih dahulu dicari jawaban atas pertanyaan siapakah yang akan menghayatinya sebagai salah satu sarana pengisi rohnya.

Misalkanlah teater tradisonal yang pernah hidup dan jaya di Riau seperti Makyong, Mendu, Mamanda, Randai Kuantan dan Sandiwara Bangsawan. Siapakah yang akan menjadi pengisi rohnya? Inikan menjadi persoalan lain, apakah kemudian seni pertunjukan teater tradisonal itu setelah berada di titik puncaknya di masa lampau, masih bisakah mengemban misi yang pas demi kehidupan yang kita jalani hari ini?

Ediruslan PE Aamanriza dan Hasan Junus pernah mengatakan dalam sebuah bukunya berjudul Seni Pertunjukan Tradisonal (Teater Rakyat Daerah Riau), bahwa hasilhasil ciptaan seni yang paling pas bagi kita hari ini adalah hasil ciptaan seni masa kini, bukan yang tradisional. Para pemikir kesenian dan kebudayaan sudah banyak membahas soal ini.

Menurut penulis, persabungan dan pertembungan pendapat mengenai hal 
di atas, senantiasa membina iklim yang sehat sejauh persabungan dan pertembungan itu didasari dari keinginan untuk mencari kebenaran dan bukan sekedar lagak dari sikap arogansi saja.

Yang kemudian, penulis pikirkan dan hendak penulis ketahui adalah di mana posisi hasil-hasil seni tradisonal dalam kehidupan masa kini dan apakah kesenian tradisional hanya layak dan pantas ditempatkan pada masa lampau saja atau berada di ceruk kampung saja, atau jangan-jangan ada gejala dan pengaruh besar dari semua bentuk seni pertunjukan tradisional itu terhadap seni pertunjukan hari ini, terutama teater di Riau.

\section{G. Keberadaan Tonil di Bengkalis}

Dalam sosok dan jiwa berkesenian di Riau, akan secara terang maupun samar ditemukan bias dan pengaruh serta sumbangan Arab, Parsi, India Cina dan Eropa, bahkan pengaruh dari sekitarannya seperti Minangkabau, Bugis, Banjar, Jawa dan lain-lain. Pengaruh dan bias itu pula justru menambah kekayaan bentuk dari sebuah kesenian karena sesuatu yang bernama kebudayaan tidaklah membawa pengaruh buruk, hanya ampas kebudayaanlah yang berpengaruh buruk.

Demikian juga dengan keberadaan Teater Tradisi Bangsawan dan tonil.
Sebuah seni pertunjukan yang kononnya tercatat berasal dari Pulau Pinang di Semenanjung Tanah Melayu pada beberapa dasawarsa terakhir abad ke-19. Di pulau tersebut, banyak dihuni oleh penduduk yang berasal dari India (Selatan).

Ke tempat itulah, pada tahun 1870-an datang suatu rombongan wayang dari India dan cukup lama menetap di sana. Karena corak seni pertunjukan mereka belum pernah dikenal sebelumnya oleh masyarakat tempatan, perkumpulan itu menjadi cepat terkenal dan menjadi panutan. Penduduk kala itu menyebutnya Wayang Parsi dan Mendu sedangkan kelompok mereka menamakannya Indra Sabor.

Benih-benih yang telah disemai oleh kedatangan Wayang Parsi ke Pulau Pinang itu merecup tumbuh bukan saja di seluruh kota-kota di Semenanjung dan Singapura tetapi juga di kesultanan-kesultanan Melayu di Sumatera Utara seperti Langkat, Deli, Serdang dan Asahan. Bahkan sampai ke Kesultanan Melayu di Riau seperti Riau-Lingga, Indragiri, Kerajaan Siak.

Ketika Wayang Parsi sudah tamat, banyaklah kemudian lahir sebuah genre baru yang disebut Bangsawan atau Wayang Bangsawan. Di Riau sendiri, penamaan itu kemudian menjadi sebutan Sandiwara 
Bangsawan yang sangat populer di daerah pesisir seperti Dumai, Bengkalis, Siak dan Selat Panjang.

Mengapa diberinama Sandiwara Bangsawan? Menurut salah seorang pelaku di Bengkalis, Suhaimi, hal itu dikarenakan kisah atau cerita di dalam seni pertunjukan itu hampir semua kisahnya mengenai raja-raja. Itulah sebabnya dinamakan Sandiwara Bangsawan.

Namun kemudian, terdapat perbedaan yang jelas antara Wayang Parsi atau Indra Sabor dengan Bangsawan, diantaranya terdapat pada kata pengantar. Jika Wayang Parsi menggunakan bahasa India, Sandiwara Bangsawan menggunakan bahasa Melayu. Perbedaan lainnya adalah kisah-kisah dalam suguhannya, tari dan nyanyi. Tari dan nyanyi dalam Sandiwara Bangsawan memanfaatkan tari dan nyanyi yang sudah sedia ada dalam kandungan kebudayaan Melayu.

Seni pertunjukan Sandiwara Bangsawan yang mencapai puncak pada tahun 1920-an kemudian berhadapan dengan suatu genre seni pertunjukan yang lain, yang baru sosok dan penampilannya, yaitu keberadaan Tonil yang menjadi cikal bakal sandiwara modern dengan pesat.
Di Bengkalis, keberadaan tonil diperkirakan cukup populer sekitar tahun 1960-an. Seni pertunjukan itu merupakan hasil dari perkembangan sandiwara Bangsawan. Hadirnya tonil itu selain dari hasil akulturasi budaya setempat dengan wayang parsi (asal sandiwara Bangsawan), juga merupakan produk penyederhanaan dari konsep pemanggunangan dari teater Bangsawan.

Namun kemudian, yang menarik untuk diteliti adalah pengaruh pola tingkah masyakarat di dalam seni pertunjukan tonil tersebut, terutama apa yang disebut dengan istilah ogam.

\section{H. Ogam Dalam Keseharian Masyarakat Kabupaten Bengkalis-Riau}

Kata Ogam termasuk dalam bahasa Melayu arkaik oleh karenanya tidak ditemukan di dalam kamus Bahasa Indonesia. Dalam konteks keseharian, ogam bagi masyarakat Melayu Bengkalis juga menjadi semacam kebiasaan dalam sebuah percakapan atau perbualan ringan yang dilakukan di beberapa kesempatan. Semakin bagus seseorang mengogam lawan bicara, biasanya pembicaraan jadi semakin menarik. Namun demikian, tak jarang pula, disebabkan tersalah ogam, perbincangan yang sedang asik dilakukan bisa terhenti seketika. 
Fenomena Ogam dalam keseharian masyarakat Kabupaten BengkalisRiau juga salah satunya, ditandai dengan keberadaan kedai kopi yang sangat banyak. Di tiap-tiap jalan di Bengkalis, terdapat kedai kopi. Di mana di sanalah dapat ditemukan pembicaraan yang dipenuhi pola tingkah ogam. Di sanalah kemudian dilahirkan salah seorang tokoh sastra lisan asal Bengkalis bernama Yong Dolah. Lewat cerita-cerita imajinatifnya itu kemudian karya sastra lisan yang dihasilkan diteliti oleh beberapa mahasiswa dan juga ditelaah oleh pakar-pakar sastra.

Proses ogam itu sendiri dapat dijelaskan secara sederhana bagaimana upaya lawan bicara terus memberikan tanggapan yang positif sehingga sang pembicara terus berbicara dengan penuh semangat. Bahkan dalam proses itu, terjadi juga ungkapan-ungkapan perbantahan namun justru tidak melemahkan si pembicara tetapi justru menambah argumentasi-argumentasi pembicara untuk meyakinkan si pendengar atau si tukang ogam tersebut.

\section{Ogam Dalam Seni Pertunjukan Tonil}

Disebutkan sebelumnya, tonil merupakan cikal bakal teater modern di Riau. Pemain di dalam seni pertunjukan ini tidak menggunakan teks atau naskah sebagai panduan dialog dalam lakon. Sebagai seorang pelakon, mereka hanya perlu menguasai jalan cerita saja. Para pelakon tonil hanya menuturkan dialog-dialog secara spontan atau berimprovisasi berdasarkan jalan cerita yang diberikan pengarah.

Seperti dijelaskan salah seorang pelaku tonil, Suhaimi, proses ogam di dalam seni pertunjukan adalah sebuah upaya yang dilakukan seorang aktor untuk memberi pancingan kepada aktor lainnya agar menghasilkan dialogdialog yang menarik dan menggelitik hati penonton. Sehingga aktor yang memberikan pancingan tersebut sering disebut dengan Tukang Ogam. Semakin bagus pancingan yang dilemparkan kepada lawan main, maka biasanya, permainan para aktor semakin menarik.

Di sini dapat ditemukan, adanya peralihan pola tingkah dalam keseharian yang kemudian mempengaruhi seni pertunjukan yang hidup di tengah-tengah masyarakat. Sebagaimana di dalam seni pertunjukan tonil, apa yang penting dalam pementasan itu adalah keaslian cerita yang dilakonkan. Kearifan pelakon berimprovisasi atau dalam proses ogam itu terkeluar dari dialogdialog para aktor. Kemudian, itulah yang menjadi daya tarik utama penonton untuk menonton pementasan tersebut, selain pelakon yang gagah 
dan cantik. Sesuatu lakonan di dalam tonil dianggap lengkap apabila terdapat unsur lucu dan melodrama selain daripada unsur-unsur kebenaran sebagai pokok cerita yang bernada serius.

Dengan demikian, dapat ditemukan relevansi kehidupan dalam seni pertunjukan. Bila disadari, dengan menggali dan mengkaji kekuatan dan keuniversalan seni tradisi, akan ditemukan kekuatan-kekuatan konsep yang dimiliki oleh tradisi itu sendiri. Bagaimana mungkin tradisi akan ditepis begitu saja setelah memberikan identitas dan kekuatannya pada hari ini. Bahwa yang tradisi tetaplah harus bernafas, sedangkan karya-karya modern berjalan beriringan sesuai dengan kehendak zamannya.

\section{J. Simpulan}

Dari banyak paparan yang telah disusun, terdapat beberapa hal yang menjadi catatan penting untuk disimpulkan penulis. Kesemuanya merujuk kepada hasil kajian yang telah dilakukan pada objek Ogam dan relevansinya dalam kehidupan keseharian dan seni pertunjukan.

1. Kata Ogam tidak ditemukan di dalam kamus Bahasa Indonesia karena kata tersebut termasuk dalam bahasa Melayu lama atau tua. Namun kata tersebut dapat dipahami sebagai sebuah upaya yang dilakukan seseorang untuk memberi pancingan atau respon kepada lawan bicara agar menghasilkan perbincangan yang menarik. Semakin bagus respon, pancingan atau ogam yang disampaikan kepada lawan bicara, biasanya dialog yang berlangsung akan semakin menarik pula.

Ogam dalam seni pertunjukan teater tradisional, secara sederhana dipahami sebagai upaya para pelakon dalam memberikan respon atau tanggapan di setiap adegan. Hal itu akan menghasilkan dialog dan laku yang menarik antara sesama pelakon. Dialog dan laku yang diperagakan dengan penuh semangat itu, akhirnya menjadi daya tarik tersendiri dalam sebuah pertunjukan. Ogam dalam pertunjukan teater tradisional juga, bisa berlangsung antara pemain dengan penonton. Misalnya dalam sebuah adegan ketika pelakon bertanya kepada penonton, kemudian dijawab oleh salah seorang maka dialog dan laku bisa berkembang antara pelakon dan pemain.

2. Setiap teater tradisional itu memiliki ciri, bentuk dan konsep masing-masing sesuai dengan kebudayaan di mana ia berada. Bentuk dan konsep yang dimiliki itu membentuk struktur tersendiri pula. Struktur yang dimaksud adalah serangkaian unsur-unsur sekaligus totalitas sebagai suatu kesatuan yang utuh dari sebuah karya teater. 
Demikian juga dengan tonil yang tidak terikat pada struktur dramaturgi yang sudah baku, tetapi totalitas kegiatan yang dilalui dalam pertunjukan membentuk unsur-unsur sendiri bagi pertunjukannya.

Hampir semua elemen di dalam pementasan saling berkoordinasi sehingga dramaturgi di dalam tonil tidak hanya prosedur atau acuan baku tetapi ianya mengalami perkembangan sesuai dengan pola dialog, laku, nyanyi, musik dan situasi keadaan dan penonton, sutradara. Secara sederhana konsep dapat dipahami sebagai rancangan.

3. Tidak dapat disangkal, keberadaan ogam dalam keseharian masyarakat, terdapat pula dalam salah satu pertunjukan tradisional TOnil di Bengkalis. Hal itu disebabkan, teater tradisonal tidak memiliki teks atau naskah utuh untuk dijadikan sebagai acuan jalannya cerita dan adegan. Dengan demikian, ogam di dalam pertunjukan Tonil juga berfungsi sebagai upaya yang dilakukan oleh pemain atau pelakon untuk meneruskan jalannya cerita secara spontan layaknya dialog keseharian. Namun terlebih dari itu, ogam menjadi "bumbu penyedap" cerita karena tak jarang ogam dalam pertunjukan Tonil biasanya bersifat humor dan komedi.

\section{Daftar Pustaka}

Pe Amanriza, Ediruslan. 1993. Seni Pertunjukan Tradisional (teater rakyat) Daerah Riau. Riau: Departemen Pendidikan Provinsi Riau.

Sedyawati, Edi. 1981. Pertunjukan Seni Pertunjukan. Jakarta:Penerbit Sinar Harapan.

Somanto, Bakdi. Kadarisman, Effendi. Ect. 2005. Seni Pertunjukan Indonesia (Menimbang Pendekatan Emik Nusantara). Surakarta: The Ford Foundation \& Program Pendidikan PAscasarjana STSI Surakarta. 